\title{
Strategies for Promoting Social Justice in Math Classroom
}

\author{
${ }^{1}$ Ram Krishna Panthi, ${ }^{2}$ Bal Chandra Luitel, ${ }^{3}$ Shashidhar Belbase \\ ${ }^{1}$ Mahendra Ratna Campus, Tahachal, Tribhuvan University, Kathmandu, Nepal \\ ${ }^{2}$ School of Education, Kathmandu University, Hattiban, Lalitpur, Nepal \\ 3University College, Zayed University, Dubai, United Arab Emirates (UAE) \\ e-mail: shashidhar.belbase@zu.ac.ae
}

\begin{abstract}
Abstrak
Artikel ini bertujuan untuk menjelaskan beberapa strategi yang digunakan oleh guru untuk memperkenalkan sikap adil di kelas matematika. Metode penelitian kualitatif deskriptif digunakan untuk mengkonstruksi, menganalisis, dan menginterpretasikan data hasil penelitian melalui proses iteratif. Tiga orang guru matematika dan siswanya (satu siswa untuk satu guru) dipilih sebagai subjek penelitian yang dipilih secara purposive dari tiga sekolah menengah umum di Kathmandu. Narasi kualitatif dihasilkan melalui wawancara yang mendalam dan observasi kelas pada masingmasing subjek penelitian. Analisis data dilakukan melalui beberapa proses analisis tematik dan interpretasi narasi dari data wawancara. Secara keseluruhan enam tema muncul dari analisis data. Tema-tema ini meliputi konseling dan dorongan, kerja kelompok dan pembelajaran kooperatif, menghubungkan matematika ke kehidupan sehari-hari, cara pengajaran yang dipersonalisasi, memperkenalkan lingkungan yang menyenangkan, dan kerja kelompok dan proyek.
\end{abstract}

Kata kunci: social justice dalam pendidikan matematika, penyelidikan interpretatif, pedagogi secara sosial

\begin{abstract}
The purpose of this paper is to discuss the strategies used by the teachers for promoting social justice in the math classroom. An interpretive qualitative research method was applied for data construction, analysis and interpretation through an iterative process. Three math teachers and their three students (one for each teacher) were selected as the research participants purposively from three public secondary schools in Kathmandu. Qualitative narratives were generated through in-depth interviews and classroom observations with each participant. The data analysis went through multiple layers of thematic analyses and interpretations of the narratives from the interview data. Altogether six themes emerged from the analysis of the data. These themes include-counseling and encouragement, group work and cooperative learning, linking math ematics to daily life, personalized way of instruction, promotion of joyful environment, and class work and projects.
\end{abstract}

Keywords: social justice in mathematics education, interpretive inquiry, socially just pedagogy

How to Cite: Panthi, R.K., Luitel, B.C., \& Belbase, S. (2018). Strategies for promoting social justice in mathematics classroom. International Journal on Emerging Mathematics Education, 2(1), 17-38. http://dx.doi.org/10.12928/ijeme.v2i1.6809

\section{INTRODUCTION}

This study argues that the emerging conditions that predominates mathematics classrooms should not be taken for granted, and that alternative approaches towards teaching mathematics should be adopted to address issues of equity, fairness, and social justice. Past results in national tests for School Leaving Certificate (SLC) examination in Nepal indicates that students of some ethnic groups, for example, Tharu, Tamang, and Yadav with literacy below the national average had low pass percentages in mathematics. Moreover, there is a variation of SLC examination result with poor performances in the 
mathematics subject that students have historically found difficult (Mathema \& Bista, 2006). Further, Mathema and Bista (2006) conclude and recommend that the curriculum should focus on the learning competencies directed towards mathematics skills practically applicable to daily life. Children from ethnic minorities in Nepal have difficulty in integrating their knowledge and skills from home culture to school and classroom. The way they learn skills in their community and home situation might be different from the classroom setting that is dominated by the mainstream cultural and political context. The national curriculum and textbooks of mathematics do not include the identity of ethnic minorities and indigenous nationalities as part of the pedagogical negotiation in the classroom. The neutralization of mathematics curricula, textbooks, and pedagogies have been silently favoring the ethnic and linguistic majority disempowering the rest of the ethnic groups and their cultural values. There is pervasive domination and discrimination on the minority groups socially, economically, culturally, and politically. This discriminant practice had not been recognized and addressed by the government of Nepal for long (Bhattachan, 2003). The result is the low performance of students in mathematics from the ethnic minorities. Therefore, the teaching techniques should be improved in a way that children from all sections of the society feel comfortable and find mathematics learning joyful and useful.

Although the matter for equity has ever become more important in mathematics education, there is still little agreement on how the term should be defined and work towards equity in classroom learning. The terms 'equity' and 'social justice' are used interchangeably. Mathematics education needs to eliminate the conflict of interest from different ethnic, linguistic, and cultural groups for social justice (Esmonde \& Caswell, 2010). Through the lens of access, all students should have equal opportunity to study and learn mathematics (Vomvoridi-Ivanovic \& McLeman, 2015). Vomvoridi-Ivanovic and McLeman emphasize that the use of equity is valuable and challenging in teaching and learning mathematics and this view is equally applicable in Nepali context and elsewhere. To some extent, equity is also demonstrated through student's achievement. Standardized tests in a global context indicate achievement gap in terms of gender, race and socioeconomic status (Esmonde \& Caswell, 2010). These elements also affect social justice in the classroom. Therefore, addressing the issue of achievement in mathematics, teachers need to be careful about different features such as race, class, ethnicity, gender, beliefs, and proficiency. These factors create a challenge for teachers to reduce achievement gap among students. Mathematics teachers need to apply different techniques such as discussion, interaction, practical action and group work, project work, participatory approach and student-centred techniques. For example, the different ideas adopted for social justice in mathematics classroom can be -- (i) employing collaborative, discursive, problem-solving, and problemposing pedagogies, which promote the engagement of learners with mathematics; (ii) recognizing and drawing upon learners' real-life experiences to emphasize the cultural relevance of mathematics; (iii) promoting mathematical inquiries that enable learners to develop greater understanding of their social, cultural, political, and economic situations; (iv) facilitating mathematical investigations that develop learners' agency, enabling them to take part in social action and realize their foregrounds; and (v) developing a critical understanding of the nature of mathematics and its position and status within education and society to maintain equity in the classroom (Wright, 2016).

Why is the idea of social justice so important in our mathematics classroom? Villegas (2007) points out that social justice agenda prepares teachers to assist all students "participate equitably in the economic and political life of [a] country" (p. 372). He explains social justice in terms of preparation and participation of students in the classroom to prepare them for democratic and socially just life practices. Social justice agenda in

IJEME, Vol. 2, No. 1, March 2018, 17-38. 
mathematics teacher education may help prepare teachers who can teach all students well and enable them to participate in social context. Planas and Civil (2009) take the definition a step further, defining social justice as "equal access to opportunities to participate in social construction of reality, and access to opportunities to improve the living conditions of individuals and groups" (p. 392). However, such practice should be linked to one's identity without which students may lose the credibility of socially just pedagogy. The teachers' focus should be not only in equity and access in participation, but it should be directed toward reducing the achievement gap.

Gutierrez (2008) points out that achievement gap can be a serious issue as there is a danger of losing identity by marginalized students and creating a position by dominant groups as a norm which others should achieve. Thus, achievement gap is a critical factor in the context of Nepal too. Therefore, there is a need to decrease the achievement gap in school mathematics. To achieve this goal, the marginalized students need scaffolding for uplifting their performance in classroom. They need counseling and cooperation from their teachers and student friends. Teachers need to design projects and lesson activities in which all students are engaged in learning through project and lesson works, and teachers facilitate them in such activities. Teachers need training and skills to implement such practices successfully. That means teacher knowledge, skills and academic capacity are necessary, but not sufficient for maintaining equity and providing equal access to all students from different ethnic and cultural background (Esmonde \& Caswell, 2010). In this context, Gutierrez (2009) suggests that teachers should embrace the tension of "teaching mathematics and not teaching mathematics that allows teachers to develop their own authentic practices and political clarity around issues of equity" (p. 14).

Despite representing important pedagogical and philosophical notion, the argument is that transforming curricula and cultures of school lack social and structural realities faced by marginalized students outside of school (Martin, 2003). Therefore, it is a challenging task for math teachers to apply a socially just pedagogy in classroom. For this, we need to find the ways how equity in terms of performance within and between diverse groups of genders, socio- economic status, and ethnicities can be addressed properly (Lim \& Pateman, 2013). This means, we need to address diversity, inequity, and injustice through socially just pedagogies in classroom teaching (Panthi, 2016). Additionally, we need to allow freedom to our students to select mathematical tasks and solve them so that they take responsibility for their own learning. To reiterate, all students from the different ethnic groups or gender should get equal opportunity in their classroom. There should not be any kind of discrimination among students based on their gender, language, cultures, and activities. Burton (2003) argues, there should be a "shift from equity to a more inclusive perspective that embraces social justice" (p. xv). Another approach to achieve this objective would be to apply the notion of ethnomathematics and use of ethnomathematical modeling. Taylor and Luitel (2005) suggest that mathematics lessons should be contextualized by adding ethnomathematics to it. Further, they emphasize on the critical aspects that associate with the Western and provincial mathematics. Addressing the issues of social justice in terms of equity, access, and inclusiveness in mathematics education is a growing area of concern (Boylan \& Woolsey, 2016).

This paper is a part of study on 'Social Justice in Mathematics Classroom: An Interpretive Inquiry' (Panthi, 2017). A part of this study incorporates 'Teachers' Perception of Social Justice in Mathematics Classrooms' (Panthi, Luitel, \& Belbase, 2018). The aim of this paper is to explore three high school teachers' strategies in promoting social justice in their classroom. Therefore, the research question that guided the study was-- What strategies do mathematics teachers apply to promote social justice in mathematics classroom? The 
theoretical frame for the study consisted of three dimensions of social justice-- social justice in pedagogical practice, social justice in educational policies, and social justice in mathematics curricula. These dimensions have been discussed separately in the next section.

\section{Dimensions of Social Justice}

Social justice seems a complex phenomenon when it comes to education in general and mathematics education in particular. Many scholars link this phenomenon to political, cultural, and economic justices. Keddie (2011) suggests that schools should give inclusive environments, where marginalized voices are heard (political justice), marginalized culture is recognized and valued (cultural justice), and marginalized students are supported in their academic achievements to successfully gain material benefits of society (economic justice). Social justice in math classroom can be viewed broadly from three lenses while observing teachers' strategies-social justice pedagogy in practice, social justice in educational policies, and social justice in mathematics curricula. We frame the current study for the stated research question within these three dimensions of social justice. We discussed each of them in the following subsections.

\section{Social Justice Pedagogy in Practice}

Social justice pedagogy is associated with classroom practices of teachers and students to maintain inclusive, adaptive, and equitable teaching and learning of mathematics. Such methods may reduce the achievement gap which is critical in Nepalese mathematics education. The National Curriculum Framework for School Education in Nepal states, "The teaching methods should be practical and effective in order to transform the learning achievements set by the curriculum" (CDC, 2007, p. 20). This framework highlights the existing problems related to the school calendar, qualification of head teachers, teaching resources, school-community relationship, extracurricular activities, student-teacher-parent interaction, teacher-teacher interaction, assessment practice, and technology in teaching learning (CDC, 2005). These problems clearly shed light on the perpetual practice of socially unjust pedagogy in a math classroom. In this context, UNESCO states-

"Male-female gender gap though decreasing is still noticeable and prevails across almost all castes and ethnic groups, rural and urban areas, eco-zones, development regions, and income groups. Huge gaps exist in educational access in terms of gender, social groups, location, disabilities, and level of income. The quality of education and students' learning achievements at all levels of education (from kindergarten to higher education) remain one of the foremost challenges of the education sector in Nepal." (UNESCO, 2015, p. 6)

The gender gap has been considered as one of the major concerns in the educational outcomes in Nepal due to poor implementation of culturally relevant pedagogy (Panthi \& Belbase, 2017). Also, there is a huge disparity in the educational attainment of students in general and mathematics in particular, based on other socio-economic factors beyond gender due to lack of educational support to the students of ethnic minorities and indigenous nationalities in Nepal. These issues are related to social justice pedagogy in practice in mathematics classes.

There are different faces of social justice pedagogy in practice. Some scholars, for examples Harrison's (2015) study, apply meaning-making process relating to the notion of social justice pedagogy and instruction that helps students and teachers to uncover the issues of social justice in a math classroom. In other research, for example, Hempel-

IJEME, Vol. 2, No. 1, March 2018, 17-38. 
Jorgensen's (2015) study, the focus is on social justice in the classroom that raises a question of social justice by analyzing pupils' ranking using competence pedagogy and ideal pupil (i.e. intelligence and good humor). Bartell's (2013) study focuses on notions of instruction of mathematics for social justice by promoting participant encouragement, mutual analysis of classroom experience and evaluating and reforming instruction. While doing this, teachers can prepare students for high-stakes mathematics tests, and at the same time, they can teach meaningful mathematics to prepare the students for future lives (Gregson, 2013). Likewise, The National Council of Supervisors of Mathematics (NCSM) and TODOS: Mathematics for All (TODOS) (2016) suggests systemic approach for social justice in mathematics teaching with "high expectations for all students, access to rich, rigorous and relevant mathematics, and strong family/community relationships to promote positive mathematics learning and achievement" (p. 1). Such pedagogy should be able to create a positive image of mathematics, reducing the negative anxieties, and developing and promoting positive attitudes (Belbase, 2013). Therefore, social justice pedagogy is a possibility for equity, access, and empowerment of students from different ethnic minorities. It is a process to create conditition for students to learn through reflective practices and reflexive thinking (Belbase, Luitel, \& Taylor, 2008).

\section{Social Justice in Educational Policies}

The issue of social justice is gaining a momentum in the educational plans and policies in Nepal in recent years. The divide of the education system as private and the public is one of the much-debated issues related to social justice in education in general and mathematics education in particular, in the country. The private and public education system in the country has produced two kinds of mentality with social implications leading to the division of the society. These problems reflect in the educational outcomes of public schools with low performance of students compared to the private schools (MOE, 2015 as cited in Panthi and Belbase, 2017). The government framed The National Curriculum Framework to help schools to frame their teaching and learning as per the government directives and policy. The National Curriculum Framework for School Education in Nepal 2007 states that:

From the point of view of access and equity, the principle of positive discrimination needs to be adopted for the expansion of education. Therefore, the nation should make special provision for women, helpless and senior citizens, orphans with disability and economically and socially backward community. Furthermore, it should safeguard the right to education in mother tongue, guarantee the child rights and provide free basic education. (CDC, 2007, p. 19 as cited in Panthi et al., 2018)

Hence, the document shows the policy of the government to provide equal access to education for all despite gender, age, and status of one's life (Panthi \& Belbase, 2017). However, there is no seriousness in the concerned authorities to improve the quality of public education in Nepal leading to further deterioration of school mathematics curricular practice in the classrooms. As a result, there is a huge difference in student achievement in mathematics across the geographical locations, ethnic minorities and majorities, and gender (MOE, 2015). Recent study on National Assessment of Student Achievement (NASA) reported that -

In mathematics, the average achievement score is $57 \%$ in the private schools whereas it is $26 \%$ in the community (or public) schools. However, it is not clear whether it is due to the effectiveness of instructional processes in the 
institutional schools or manifestation of the disparity of socio-economic status of students in these two different school systems. (MOE, 2015, p. vii)

The disparity reported above in the achievement in private and public schools has been one of the major sources of social inequity in mathematics education. The report highlights that there is also a difference in the achievement of Dalit and some Janajati students compared to students from the majority communities in Nepal (MOE, 2015). The report further indicates that there is a wider gap in the students' achievement between rural and urban schools in Nepal. The achievement gap is about 24\% in the grade 8 (MOE, 2015).

Recently, the Government of Nepal, Ministry of Education unveiled school sector development plan (SSDP) 2016/17-2022/23 which mentions about equity and inclusion. This policy document states, “... there has been significant progress on strengthening equity, and there is now gender parity on a number of basic and secondary education indicators" (p. 28). The same document states that there are still "many differences remain with children receiving inequitable access to quality education due to gender, socioeconomic status, language, ethnicity, caste, geographical location and differing abilities" (p. 28). Realizing these issues, SSDP has suggested for strategic interventions by consolidating equity-based strategies, using disparity-based formulas and indexes, strengthening the evidence base and rationalization criteria and modalities of scholarships, and strengthening the institutional capacity to provide inclusive education for all children (MOE, 2017).

When it comes to education policy in the country, the new constitution of Nepal (2015) has guaranteed the right to education in mother tongue until high school. It states that "Every Nepali community living in Nepal shall have the right to acquire education in its mother tongue up to the secondary level, and the right to open and run schools and educational institutions as provided for by law" (Part 3, 31.5) (Panthi \& Belbase, 2017). We can see that this provision is not a new one because Nepal had a similar provision in the Interim Constitution 2007. Recently, the Ministry of Education introduced the National Education Framework for School Education in Nepal 2007 (UNESCO, 2011) which embarks upon curriculum reform based on equity and access to mathematics education. However, the implementation part is one of the primary concern of skeptics of education in Nepal due lack of clarity in vision, mission, and enactment of educational plans and policies.

Social justice in educational policies "relate to equal opportunities and desegregation of higher education" (John, 2007, p. 68). The educational policies should create opportunities for all in education by implementing and enhancing equity indicators. There are three key elements in social justice in education policies-- first, bringing excluded and marginalized students to the fore; second, applying social justice audit to assess the effectiveness of social justice policy in practice; and third, adopting redistribution of resources in a fairer way and recognizing the cultural and social identity (Thrupp \& Tomlinson, 2005). However, there is ongoing controversy in policy and implementation in practice. Bull's (2009) analysis of social justice in education policies unveils some of these controversies in relation to multiculturalism, accountability, and demands of educational standards.

\section{Social Justice in Mathematics Curricula}

School mathematics classrooms in Nepal are multicultural, multilingual, and multiethnic in general. The students come to the school from different cultural, social, and linguistic background (Panthi \& Belbase, 2017). It is common not only in Nepal but also an emerging issue in other parts of the world where the there is growing multiculturalism. This situation can be both an opportunity and a challenge in mathematics education. According to Gates (2006), "in many parts of the world, mathematics teachers are facing the challenges

IJEME, Vol. 2, No. 1, March 2018, 17-38. 
of teaching in multi-ethnic and multi-lingual classrooms containing immigrant, indigenous, migrant, and refugee children, and if research is to be useful it has to address and help us understand such challenges" (p. 391). We share the similar context in Nepal as expressed by Gates (2006) because of multi-lingual and different minority ethnic groups have their own problems in a classroom context in any part of the world. The classroom issues in Nepal are related to historical discrimination and domination on ethnic minorities and indigenous nationalities, internal refugees and migrants due to the past ten-year conflict in the country, non-representation or nominal representation of ethnic minorities in the government bodies, and post-conflict political instability (Panthi \& Belbase, 2017). These issues are creating challenges in the social, political and economic development of the country at one side and they are perpetuated as hindering factors in teaching and learning mathematics to the other side. The mathematics curricula designed by experts and implemented by the government to all grade levels do not commensurate with the minority and local culture. Mathematics curriculum, in general, has been imported from the Minority World (Luitel, 2009) and has been imposed upon the teachers and students in Nepal. The National Curriculum Framework for School Education in Nepal states that "The notion- education should be based on local needs in order to address the local necessity- has already been globally acknowledged" (CDC, 2007, p. 22). The framework suggests for formulation and implementation of local curricula focusing local contents, integration of local contents to main curricula, and developing resources to support such curricular practices.

The notion of justice in mathematics curricula started with the declaration of National Council of Teachers of Mathematics (NCTM) in 1989 that equity as a part of mathematics education (NCTM, 1989). This suit has been extended in the Principles and Standards of School Mathematics (NCTM, 2000). In its equity principle, NCTM (2000) states that "Excellence in mathematics education requires equity-high expectations and strong support for all students" (p. 2). Besides mentioning equity, multiculturalism, and social justice as guiding principles in curricula of mathematics, there are other areas to focus on. Gutstein (2009) highlights some complexities of social justice in mathematics curricula in terms students' social realities and mathematics as a 'gate-keeping' for higher education. Mathematics curricula can be considered as a synchronous of community knowledge, critical knowledge, and classical knowledge (Gutstein, 2009). Hence, social justice mathematics curricula can be viewed from students' roles, identities, social realities, and knowledge boundaries. Such curricula should be able to impart positive image of mathematics (Lamichhane \& Belbase, 2017) by reducing mathematical anxieites and developing positive attitudes through a transformative approach to pedagogy through metamorphosis of teachers (Belbase, 2006).

\section{RESEARCH METHOD}

We employed qualitative interpretive inquiry as a research approach for this study. Interpretive inquiry relies on the normative or evaluative facts of data input, process, and outcome that best justifies the entire set of practices in which that concept is used (Plunket, 2013 as cited in Panthi et al., 2018). An interpretive inquiry develops knowledge assertions from the interpretation of lived experiences of the participants focusing on strategies of social justice in the mathematics classroom. Knowledge, as interpretivism claim, is generated as we interpret new experiences or new theories in the context of what we believe and what we teach (Hay, 2011). Interpretation of text in context takes the hermeneutic turn. The hermeneutic process of interpretation requires reflexivity, a process of turning one's gaze back upon oneself and paying attention to how one's own preunderstandings and situation affect the people being studied, questions asked, data being 
collected and its interpretation (Berger, 2015). This study, being a part of the first author's M.Phil. dissertation, has been commissioned into different papers from separate research questions.

The participants in this study were three public secondary level mathematics teachers and three public high school students in Kathmandu. The schools, teachers, and students were purposively selected. The schools had enrolled students from low-income families and marginalized groups. The students were from different socio-economic and cultural backgrounds. The main reason for selecting Kathmandu as the research site was based on access to schools, teachers, and students for the first author. Among different strategies of making the interpretive inquiry, this study aimed to employ in-depth interview and classroom observation to collect data from teachers and students. The first author informed the head teacher of each selected school before his visit. He visited schools and met with the participants (teachers and students) to set the interviews. He took informed consent from each of them to participate in the study. He conducted the interview with teachers and students in the Nepali language with a focus on social justice in the math classrooms. He recorded the interviews for transcribing and analyzing.

At first, the first author translated and transcribed the recorded data verbatim in English. He carried out transcribing and interpreting the data to gether that supported conceptualizing meanings and concepts from the interviews to construct narratives (Bold, 2012). Based on the meanings in the narratives of teachers and students, the first author as the researcher focused on 'what's' of the stories (rather than the structure) and identified "common elements to theorize across cases" (Reissman, 2008, p.58). The thematic analysis continued with several steps such as "reading the transcripts several times, inductive coding, developing themes and subthemes and seeking to identify core narrative elements associated with each theme" (Ronkainen, Watkins, \& Ryba, 2016, p.16). He compared different themes based on meaningful texts from critical theoretical perspective. He analyzed and re-analyzed the data until six final themes emerged out of it.

\section{RESULTS AND DISCUSSION}

The six central themes emerged from analysis of the data are-- counseling and encouragement, group work, linking mathematics on daily life, personalized way of instruction, project work, demonstration, and encouragement. Discussion of each theme followed by interpretation relates to praxis-- the interplay between theory and practice.

\section{Counseling and Encouragement}

Counseling means understanding students' personal problems and offering them advice to solve the problems. Teachers can change their students' habits of learning mathematics with the help of counseling and encouragement. Such practice helps in promoting the desire of learning mathematics by weak and marginalized students. One of the research participants Chandra states:

We need to motivate them (students) to be active and develop their positive attitudes towards mathematics, to make them able to tackle different problems. Therefore, I counsel my students. I categorize counseling into individual and group counseling. In individual counseling, motivation is given to individual students, who have special problem (economic, social, and psychological) that affects learning mathematics. But in group counseling, students with similar problems are counseled in a group. For example, at the time of earthquake, group counseling was given to reduce the tension of students. I encouraged them to do different activities such as concentrating on game, painting, filling air into balloon, etc. I tried to divert their

IJEME, Vol. 2, No. 1, March 2018, 17-38. 
mind from the critical context. I asked them not to be afraid of earthquake but to be aware of natural disaster. (Interview, 13th July 2016).

Chandra's strategy of counseling and motivation to promote social justice include caring of individual and group of students when they are distressed with the social and psychological factors. For him, it is even more important when students go through the experience of natural disasters, for example, the earthquake. According to the Chandra, a teacher can engage students in arts and games to divert their mind from the traumatic experience of loss or disaster from the earthquake.

Another research participant Saurya shares his life experiences with the students to encourage and counsel them to focus on learning mathematics. He claims:

I convince my students that mathematics is not a difficult subject. I also highlight the importance of mathematics in our life to motivate my students. I sometimes explain from my own real life examples. I give them my own example that I was a normal student in mathematics up to grade seven. When my teacher encouraged and cared daily, I did better in mathematics. My teacher would tell me not to worry about any error but to keep on practicing. I was told not to look at mathematics as a difficult subject. I was also convinced about the importance of mathematics for my students. I tell the same things to my students. Now, I feel that my students are slightly attracted towards mathematics. They listen to me more and practice the subject more. They have gradually developed their confidence in mathematics. They have also increased the habits of questioning in classroom. Thus, my counseling has developed positive attitudes in my students and motivated my students towards mathematics (Interview, 18th July 2016).

Saurya's counseling to students focuses on considering mathematics not as a difficult subject, connecting it to his own biography, and attracting students' attention to mathematics. For this, he encourages weak students in different ways such as praising students, saying 'Good!', 'Syabas!', 'Well-done!', etc. to appreciate their works. Additionally, he reinforces and rewards good works of his students. This helps to improve the activities of marginalized students. Therefore, he feels that counseling is necessary for students to enhance their skills in mathematics.

Similarly, Tara counsels and motivates weak students for the upliftment of their mathematical knowledge. He tells them not to waste time and utilize their time to learn mathematics. He believes that his counseling has upgraded weak students to medium and medium students to high level of performance. For example, a girl student, who did not have any attention towards learning mathematics in classroom, has shown her interest in mathematics after his counseling. She has also gradually improved her knowledge. She is planning to do something in mathematics subject (Interview, 21st July 2016). Tara also believes that student progresses through counseling. He gives an example of a weak boy at grade seven, who improved a lot after his counseling. Tara always encourages students through counseling. He particularly counsels the students, who do not have any interest in mathematics (Interview, 29th August 2016). Bindu said, "My teacher's counseling developed encouragement and motivate me to learn mathematical topics"(Interview, $13^{\text {th }}$ July 2016). So, it is necessary for us to promote positive attitude towards the subject. It assists to reduce some confusion about the subject.

These participants' views about encouragement and counseling for social justice indicate three important strategies: individual and group counseling, use of personal biography for motivation and counseling, and use students' performance as indicator of social justice. However, social justice is complicated and debatable issue (Bolyan, 2009). The 
success of mathematics instruction relies on stimulation to transform beliefs and action (Moscardini, 2014). Social justice counseling is a careful action for improving equity, access, participation in classroom, which supports for the enhancement of individual and circumstantial justice (Constantine et al., 2007). The aim of social justice is to eliminate the systems of oppression, inequity, inequality, or exploitation of marginalized populations and communities (Constantine et al., 2007). Further, multicultural training within academic programs has also blended these three elements into curriculum, pedagogy, and student evaluation (Jones, Sander, \& Booker, 2013). So, teachers should follow this model while teaching mathematics for promoting social justice in classroom. However, social justice training lacks practical techniques to apply in real classroom context (Jones et al., 2013).

\section{Group Work and Cooperative Learning}

He realized that it is good to organize group work in large class size. In group work, students become more active in their classroom. It promotes the feeling of cooperation. Especially, marginalized and lower achieving students can learn more from their colleagues. They have good opportunities to express their knowledge in their group so that students develop their performance.

In Chandra's class, he found that all students were divided into small groups with a good balance of gender, caste, age and capacity and they were asked to do project work in their classroom. There was a good coordination within groups and among groups (Classroom observation, 13th July 2016). He realized that group work practice also improves the tackling capacity of students in mathematics. Saurya said:

\section{I cannot care all my students individually. Therefore, I divide my students into small groups mixing at least one good student in each group. I assume that team leader teaches his/her friends. I think different students are intelligent and good at different things, such as some are clever in simplification of algebraic expressions; others are good in profit and loss. So, they share their knowledge with one other. Thus, group work brings uniformity and equity in learning. I feel easy to teach when I divide his students into different groups. I also feel that students learn more from their group work. Thus, group work helps to develop confidence in students (Interview, 18th July 2016).}

Tara supports Saurya's view. He also divides his students into different groups in the same way and assumes that students learn more from their friends (Interview, $21^{\text {st }}$ July 2016). Rekha viewed, "I learn more from group work through our sharing ideas to one another. I am more active in learning mathematics. I also cooperate to each other" (29 August 2016). The aim of group work is to gain and build knowledge together. Solving problems in groups usually involves everyone in the group work and students provide feedback to each other. Though their thought may not be same all the time, group members still reflect on their thought together. Everyone must know what is to be done and come together to agree on the problem through good discussion while working on it (Webel, 2013).

He feels that students and teachers have only slightly different ideas about the features of effective group work. Generally, they agree that effective group work involves cooperation and sharing knowledge and supporting each other. Cooperative group work also creates a good chance for social interaction and active participation. He perceived that having students to work together in small groups has many benefits that will not come from a teacher centered classroom context. Working in groups has shown improvements in students' achievement and has helped students to develop their interpersonal relationships.

IJEME, Vol. 2, No. 1, March 2018, 17-38. 
Group work creates a great learning opportunity for students (Allen, 2012). He thinks this is suitable way to improve students' performance.

In group work, students have more opportunities to express their thoughts and exhibit deeper mathematical concepts. Their own mathematical strategies can be improved because they are able to coordinate with their peers. During group work, students do not feel lonely and may feel less worried about practicing mathematics (Allen, 2012). However, they become active inquirer in their classroom. The use of group work as cooperative learning technique positively supports student learning (Kriflik \& Mullan, 2007). The projects focused on group work can also develop social and personal skills. Additionally, other vocationally oriented group work skills may enhance learning, if consideration is given to group size, formation, skills development and assessment strategies.

Teaching and Learning in small groups has an important pedagogical part to play in classroom. It allows them to make meanings, to express themselves in language of the subject, and to establish a close relationship with academic staff. It also gradually improves instrumental skills of listening, presenting and persuading (Jacques, 1991). He concludes that group work is suitable for large mathematics classroom. All the participants have a common practice that they divide their students into small groups; each of which contains good and weak students and each student shares his/her idea with other members in the group. Each student learns more from group work. The teacher is a facilitator in such groups. Group work develops personal and social skills in students. It also gradually promotes instrumental skills of listening, presenting consideration and persuading. It creates a great learning opportunity to students and helps to gain and build mathematical knowledge.

\section{Linking Mathematics to Daily Life}

The use of mathematics in everyday life includes the use of real examples in the universe. Generally, we say that mathematics is a practical subject. Thus, we need to design the curriculum according to the necessity of the culture of society. However, it is a challenging work. We connect mathematics to students' daily life activities. We do not impose theory and bookish knowledge into students as this does not sharpen students' mind. We need to make all students as creative worker. Chandra said:

My students enjoy a lot whenever I relate mathematical topics to their daily lives. I understand that mathematics should help to solve daily life problems of students. In my classroom, students raise many questions related to vector, such as why do we study vector? What is its usefulness in daily life? I tell one of the students to give him a pen. Then, I give real examples in my classroom. For instance, by using a pen, I tell them that there is a certain distance called magnitude and a direction. It is used to find the distance between two planets. I feel that students enjoy learning when real life examples are given to them. Such examples also help to make mathematics learning memorable (Interview, 13th July 2016).

Similarly, Saurya relates mathematics to daily life of students, while teaching in classroom. "I always try to link mathematics to students' real-life context. For instance, I ask students to guess how many bricks are needed to construct walls of a house and how many tiles for carpeting in the floors (Area and rate of sq. ft. is given)? I also ask them to estimate the cost of painting the ceiling, walls and floors (area, rate of sq. ft. is given). I also ask them to guess the number of days needed to complete the house" (Class observation, 29 June 2016). "Students calculate all the items very actively. I think, students' performance has slightly improved due to real life examples" (Interview, 27th August 2016). 
Likewise, Tara finds a connection between mathematics topics and students' daily life problem and supports students to tackle such problems. He reported, "I always give them practical example. For instance, I teach the topic of purchase bills and discounts. I provide original receipts (bills) and discuss about price and discounts in classroom. Sometimes, I also ask students find perimeter of the wall in their classroom by measuring the length and height and applying the formula. He argues that such kind of learning becomes long lasting (Interview, 29th August 2016). Rashin, a student, said, "I feel easy to learn mathematics that relates to daily life materials. I enjoy a lot through practical way of learning. I conceive the mathematical knowledge of the topics conveniently with real objects".

As an application of culturally relevant pedagogy, teaching for social justice challenges teachers to build specific curriculum that supports students to understand their problems that occur in their communities (Garri \& Appova, 2013). Teachers should relate mathematics to the cultures of students in which they perceive the notion of the subjects. If the subject matter is related to students' daily lives and society, students may remember it for a long time. Therefore, teachers should value students' cultures. In acknowledging interaction between mathematics and human experience, we should start to know how mathematics acts in society. Mathematics creates our experience in the universe by communicating role of school mathematics and/or organizing our daily lives via a vast array of visible and hidden mathematical technologies (Falkenberg \& Noyes, 2010). So, mathematics should be visible, behavioural and practical in the daily life.

Gutstein (2006) tries to convince that determinable ability of mathematics can give tools to find social injustice by significant discussion of real-life situations. For instance, a mathematical idea can be transformed into a dynamic consideration through pedagogic techniques to teach mathematics. Gutstein develops 'reading and writing the world with mathematics'. For instance, comparing cost and size of houses owned by different racial groups (Gutstein, 2006) allows students to apply tools to explore the ways of impacting their urban community and thereby critiquing their social reality. This and other projects described by Gutstein are examples of how teachers have helped students to improve the idea of using determinable tools to 'read one's world'. If this consideration guides students in their way of engaging with the universe around them, it becomes a 'moving idea' in Dewey's sense. Gutstein focuses on meaningful understanding and application of mathematics. I think that real understanding of mathematics supports in promoting social justice.

According to Emma (2015), the use of mathematics in everyday life means using real examples of universe which would inspire students with practical interest. For instance, the use of measurement equipment at home (use of bathroom scale), dimensions of carpet and decorators, distance-time relationship in travel, buying and selling market, averaging and statistics for costs, income, savings and so on.

He realized from Chandra's views that students enjoy a lot whenever teachers teach mathematical topics and relate mathematics to students' daily lives. Students easily understand the concepts. Other participants also support this idea. He thinks, teachers should link mathematics to students' daily lives.

\section{Personalized Way of Instruction}

The first author perceived that individualized instruction is teaching student individually. It is appropriate for low achieving students and socially backward students. But it is challenging for the large class size. He considers that it is difficult for using this technique all times in our classroom context. Teachers use it according to the needs of individual students. It is important as students sometimes may not catch the idea of teachers' mass teaching. Chandra guided and counseled students individually regarding

IJEME, Vol. 2, No. 1, March 2018, 17-38. 
their needs. Further, he gave feedback to each student in classroom and a chance to improve their individual capacity (Class observation, $16^{\text {th }}$ June 2016).

Later in his interview, Chandra reported, "out of class support is necessary for those students who have special problem i.e. those students who have less interest on subject and have insufficient basic knowledge of mathematics. My students freely ask me questions in their leisure time, because of which their performance has been improved" (Interview, 28 $8^{\text {th }}$ August 2016).

Saurya also views that, "mass teaching may not help to improve weak students in mathematics. Individual instruction is necessary for the promotion of low-level students in learning. It helps to reduce inequity in classroom. Students become more confident because of individualized instruction" (Interview, 27th August 2016). Rekha added, "Personal way of instruction is useful for me learning mathematical topics. I perceive various concepts of mathematics easily from this technique. My teacher watches and cares to me with weak colleagues personally. However, it is necessary to increase time in the classroom (Interview, 27th August 2016). Similarly, Tara views that personalized instruction is suitable for weak and marginal students. He added, "I think, it assists to bring equity in the mathematics classroom. It is suitable for the improvement of performance and ability of students. I experience that individualized instruction provides different tasks for each learner and provides support at individual level. It is based on the idea that all learners are different and therefore have different needs. So, an individualized or personally tailored approach to instruction might be more effective, particularly in terms of tasks and activities that pupils undertake and the pace at which they make progress through curriculum" (Interview, 29th August 2016).

Teachers in the heterogeneous classroom need to adapt their instruction according to individual children's need and level of academic skills, especially when children's skills and performance are poor (Rytivaara \&Vehkakoski, 2015). I realized that teachers need to instruct poor children (weak in performance) individually. Bindu, a student, viewed that her teachers emphasize procedural techniques while solving problems. She explained problems to students' clearly. Her teacher also focuses on solving problems of weak students. Rekha, another student, supported her views. I think that it helps to improve weak students' computational skills and different way of thinking. Students' academic performance depends on their teachers' instruction. Many theories have emphasized that successful education depends on adapting teaching to the needs of individual student (Nurmi et al., 2012). As teachers' instruction and classroom practices vary in many ways (Connor, Morrison \& Katch, 2004), teachers may also differ with respect to how much they adapt their instruction according to students' academic performance. Many teachers and classroom characteristics, such as teaching experience and class size, may also influence such adjustment. Thus, teachers need to support students for the improvement of individual students' learning and for better education in classroom. Mass teaching may not improve weak, slow and disadvantaged students in mathematics. So, individual instruction is especially necessary for marginalized, weak and slow students. Individualized instruction supports to bring equity in the mathematics classroom. In a heterogeneous classroom, teachers adapt individual instruction regarding individual children's need and level of academic skills.

\section{Promotion of Joyful Environment}

The research participants realized that teachers should try to make joyful classroom environment. For this, they should use different relevant materials. Also, they can teach mathematics contents using poems, songs, genre and drama where students enjoy a lot and conceive the notion of the subjects. Moving, touching things, laughing, and telling stories are prime entry points for important skills and understandings. Teachers need to try to ensure 
both engagement and understanding for all learners in every lesson. Tomlinson (1999) states, "In a healthy classroom, teacher is serious about learning"(p.32), though it might be difficult to make all topics joyful. He acknowledges Chandra's voice that when students understand subject matter, they enjoy it.

Chandra stated, "I do not punish students but motivate and counsel them to learn mathematics enjoyably. I also give them work to use mathematics tool and explain its different aspects. In this way, students feel comfortable to study mathematics, and they tend to learn more from real materials such as prism, cylinder, cube, parallelopiped, circular ring, etc. I also ask them to find the formula of area and volume of these materials. I teach students about the formula of area of triangle, area of triangular prism, area of circle, area of sphere. Similarly, I sometimes teach mathematics with the help of poems and songs. Students also sometimes compose poems in classroom and promote their ability" (Interview, 28th August 2016).

Saurya puts students in discipline but he freely allows them to ask questions when they don't understand. Students enjoy learning as he allows them to ask questions and tells jokes and IQs, before solving problems. In addition, he asks different interesting questions to his students, such as "Which mathematical sign do you use between the numerals 2 and 5 to obtain the number greater than 2?" Students think carefully and give answer. In this way, students find lesson entertaining. Enjoyment comes after understanding of mathematics" (Interview, 27th August 2016).

Tara also reported, "We can teach some topics of mathematics through games and drama. For example, for teaching profit and loss as a drama, I make one student a shopkeeper and some other purchasers. Another gets the role of a whole seller. Purchasers buy something from the shopkeepers and they pay money. The shopkeeper makes a profit and sells goods to the purchasers. However, sometimes there is loss in some items. Thus, students really understand the topic of profit and loss. I also ask them to do some measuring works, for instance, to measure the length, breadth and height of their classroom and to find out the area of four walls, floor and ceiling, perimeter of the walls, ceiling and floors, volume of the room, etc. Students do their homework and they enjoy a lot. Thus, students experience a wide range of academic emotions directly related to academic contexts (Interview, 29th August 2016).

Rashin said, "Teacher applies joyful way of teaching mathematics... It has helped to promote our knowledge of mathematics... It assists to make students concentration towards subjects. The joyful environment creates keen interest to learn the subject" (Interview, 29th August 2016).

The current investigation attempted to provide some responses to the question "how to develop beneficial intellectual desire and prevent or minimize, or alter negative ones by focusing on desire, intellectual enjoyment and intellectual discouragement'. Sakiz, Pape and Hoy (2012) define intellectual enjoyment as a positive activating desire experienced when the engagement in a task is joyful, pleasant, and satisfying. In learning environments, I felt that lack of enjoyment leads to feelings of boredom accompanied by disengagement from activities. Teacher characteristics may affect students' emotional experiences. In a study involving elementary school students in Brunei, teacher proximity (e.g., closeness) was found to be positively associated with students' enjoyment in science classrooms (Brok, Fisher \& Scott, 2005). Pekrun (2006) argues that the way intellectual desires (intellectual enjoyment and intellectual discouragement) arise in social contexts is clear, but the way positive desires are promoted, or negative desires are prevented is still not clear.

To conclude, as Chandra said, when students understand mathematics, they can enjoy it. Tara teaches some topics of mathematics such as profit and loss games through drama and games. I think that the curriculum of mathematics should be contextualized so that teachers can link it with students' real lives, which promotes meaningful understanding and

IJEME, Vol. 2, No. 1, March 2018, 17-38. 
students' happiness. The academic desire i.e. academic enjoyment and discouragement arise in social situation. Positive desire should be promoted, and negative desires should be prevented.

He perceived that demonstrating relevant materials and non-materials in classroom develops thinking capacity of students. The physical objects which students can see, touch and feel are real materials, but non-materials are related with teachers' knowledge and activities. The teacher should be confident, knowledgeable and skillful for classroom demonstration. They also should have the necessary knowledge of modern technology, such as a computer, an overhead projector, a smart board, and so on. Chandra clarified, "I show both materials and non-materials in my classroom. I always demonstrate materials and explain the concepts with the help of those materials. I also allow my students to touch and see the materials. For example, I make a paper cylinder and show its each component to my students. My students touch the cylinder and guess its volume. When I use real materials, all students seem to enjoy the topic and show interest to learn the concept" (Interview, 28th August 2016).

Saurya said that his students make different objects such as a cone, pyramid, and triangular prism, and demonstrate them in classroom. He added, "I explain mathematics formula related to the topic and all students try to understand the concepts and components of solid materials. Sometimes, I allow some good students to solve problem and demonstrate it to other students. Students directly see and touch real objects and understand their features" (Interview, 27th August 2016). Tara also uses similar techniques. He makes cone, cylinder, cube and triangular prism. His students also participate in making those objects. He demonstrates those objects while teaching related topics. "Students see, touch and understand different components such as area of curved surface, volume and area of total surface of those objects. It helps students to understand the concepts" (Interview, 29th August 2016). Bindu said that her teacher demonstrates the materials like cube, sphere and explains their components such as volume and surface area. Further, she added, "the teacher demonstrates some formula and important points in chart papers and the demonstration helps them to understand the concept" (Interview, 13th July 2016).

Educators believe that good relationship between teachers and students are important in the learning process. For example, when teachers demonstrate supportive and helpful interpersonal behaviours, students are more actively involved in learning, and they develop deep learning approaches (Zhu, 2013). As teacher-student relationship is integral to the learning process, it is important to equip mathematics teachers with relevant knowledge about interaction models between teachers and students.

To conclude, teachers teach their students with the help of paper and pencil and demonstrate materials, allowing students to touch and see them. They also do give different materials to students and ask them to design some objects and demonstrate them in classroom. Such activities help to improve creativity in students. From demonstration, students also become capable and develop the habits to reading, writing and discussing mathematics. They apply real objects and mathematical pattern of reasoning. I think that students promote exposing powers and skills in their classroom.

\section{Classwork and Project Work}

The first author experienced that teachers need to give classwork to students regularly. We have a belief that 'practice makes a man perfect.' But, it is expected that teachers watch and care all students. They need to help the students, who have problems. Chandra focuses on students' class work. He claimed, "Students are involved in computing and solving problems. They have opportunities to ask questions about the problems. They 
cooperate with each other and solve the problems. They also support their colleagues to understand the problems. They have a competitive environment. The teacher also facilitates them for solving the problems" (Class observation, 16th June 2016). Chandra argues that such learning becomes memorable and can sharpen their mind (Interview, 28th August 2016).

He realized that Saurya's technique support to promote social justice. He checks only the copies of group leaders. The leaders are rotated daily. As a result, all of them are responsible for doing class work. The group leaders share their mathematical knowledge to their friend in their group. The group members can ask questions to their leader, if they do not understand the concepts. Tara also gives class works to his students for about five minutes. His classwork is about the previous lesson (Class observation, 16th June 2016). Later, Tara told me that he teaches for sometimes and gives classwork to students regularly. In the classwork, students practice topic related problems (Interview, 28th August 2016). Rashin pointed out that there is examination after completing every topic in the classroom. His teacher evaluates them continuously by taking continuous assessment practice. His teacher also asks them to do classwork and homework and gives them feedback. Rashin also believes that students learn more from examination (Interview, 13th July 2015).

He realized that giving project work to students' increases their engagement in learning mathematics. It helps to deepen students' skills on any mathematical topic and to improve new mathematical knowledge. Chandra makes different small groups and asks each group to do some project work. For example, he first asks them to design cube and sphere and then asks them to justify their volume and area. They try to remember formula and concepts. They write formulas on the cardboard and paste it on a wall of the classroom (Class observation, 16th June 2016). He thinks, this work developed students' ability to understand the topics clearly. Also, that promoted behavioral learning of the students and drew their attention towards the subject. It also increased all students' performance. Thus, it promoted social justice in the classroom. Another participant, Saurya also gives different project works to his students such as measuring and finding the area of the floor of a classroom, measuring the ground and finding its perimeter (Interview, 27th August 2016). Thus, students experience real life mathematics. Saurya argues that his students understand the concept clearly when they perform such kind of works in the classroom. He realized that making different small groups in the class and asking each group to do some project works, which are related to students' real-life context, enhances learning. Rekha said, "My teacher gives classwork daily. Therefore, my friends and I involve in doing classwork. I help my weak friends for solving classwork problems. It develops my confidence in solving mathematics and related problems" (Interview, 27th August 2016).

The outcomes of this study have three major implications - policy implication, pedagogical implication, and theoretical implication. The policy implication focuses on policy intervention for social justice in the mathematics classroom through appropriate action to reform curricula, textbooks, and mode of teacher education. The pedagogical implication focuses on practical application of socially just teaching and learning in the classroom. The theoretical implication emphasises on definition, principles or ideas related to the subject but not practical. The theoretical implication may help in understanding and developing relevant theory that may guide practice. These broader implications have been discussed in the subsections as follows.

\section{Policy Implication}

This study assists teachers, experts, curriculum planners, and policy makers to understand the existing situation and practices of social justice in the mathematics 
classroom. It gives insights for transforming teaching methods, for reforming curriculum, and for promoting social justice in the classroom. The findings of study can enable teachers and students to generate relevant knowledge that is transferable to other classroom situations. The study shows how the research was undertaken collaboratively with teachers working in 'typical' classroom situations (i.e. those where common issues and constraints relating to developing practice are present) is likely to be perceived as relevant and authentic by other teachers. Such research, therefore, has the potential to increase teachers' engagement with research findings. The themes may help education policy makers in making policies for social justice in the classrooms by including counseling, group work, class work, project work and individual instruction, etc. for students learning and improving social justice in the classroom. For example, the SSDP unveiled by the Ministry of Education of Nepal in 2017 spells out some issues related to inequity and inclusiveness, but such documents need solid research-based foundation for actual implementation of policy in the schools and classrooms. The findings of this study have policy implications in the sense that it provides some practical aspects of implementing strategies of social justice in the math classrooms.

\section{Pedagogical Implication}

The teachers used seven themes (counseling, group work, class work, project work, demonstration and individual instruction, etc.) which are the ways of teaching in the classroom. They seem to apply these approaches in the classroom instruction. They counsel to their children for developing positive attitudes. They also used group work, class work, demonstration of materials and non-materials, individual way of instruction if necessary for students learning. Low performer students are beneficial more from using these techniques. These practices support in promoting social justice in the mathematics classroom. It has also highlighted how secondary school mathematics teachers and students perceive social justice and what strategies are used by teachers to face with the issues for promoting social justice in the mathematics classroom. The study also aware teachers and experts about inequity in the classroom. Thus, the lessons and problems exist within the lives and communities of the students, making this pedagogy mathematically rich, culturally responsive, and authentic. The SSDP of 2017 accepts that pedagogical approach of teachers severely affects the quality of education (MOE, 2017). There was a serious lacking in the School Sector Reform Plan (SSRP) of 2009-2015 in achieving "a major breakthrough in terms of quality and improved learning outcomes" (MOE, 2017, p. 22). The SSDP aims to improve the situation through teacher professional development, improving classroom practices, and implementing child-friendly and learner centered pedagogies. The findings of the current study may contribute in understanding classroom contexts and teachers' motivation in developing and implementing equity and access in math classrooms.

\section{Theoretical Implication}

This study is likely to bring awareness among teachers for making socially just curriculum. Enabling conditions as suggested by this study are needed to foster equitable pedagogical practices. It advocates school as an agency for social reconstruction. The critical aspect of the research design enables new knowledge to be generated. It also throws lights on the existing challenges for promoting social justice in schools and wider society. The study has outlined processes that enable the transformation of classroom practices to other situations. These themes give insights with various ideas and techniques to the stakeholders for promoting social justice in the math classroom. The research approach and the findings may contribute to the literature of social justice in education in general and mathematics 
education in particular. The six thematic constructs-- counseling and encouragement, group work and cooperative learning, linking mathematics to daily life, personalized way of instruction, promotion of joyful environment, and class work and projects add a few bricks to the world of social justice education to create equitable, inclusive, adaptive, and empowered math classroom for students of all sections of society, preserving the rights of both majority and minority pedagogy and ethnic and cultural groups.

\section{CONCLUSION}

We found from the in-depth interviews with three teachers and three students, classroom observations and analyses of those interviews and classrooms observations that teachers tend apply different strategies, such as counseling and encouragement, group work and cooperative learning, linking mathematics to daily life, personalized way of instruction, promotion of joyful environment, and class work and projects. Counseling students helps in developing positive attitude towards the subject (i.e. mathematics). Individual counseling is essential for marginal students for upliftment of their performance and participation in the classroom. Sometimes group counseling and clinical counseling is fruitful for motivation to learn mathematics. Another strategy intended by teachers to apply in the classroom is group work. Weak and disadvantaged students learn from group works easily. They share their experience one another. Teachers also link mathematics on daily life on certain topics so that students understand the content meaningfully. A personalized way of instruction is one of the essential techniques the participating teachers intended to use as one of the strategies for social justice in the math classroom. But, it is difficult in a class with large number of students to implement individual guidance. Doing project work is essential in the mathematics classroom as a means of collaboration among students. It helps students to develop creative activities.

The demonstration is another way of teaching in the math classroom in which students can visualize the materials and non-materials in the classroom. All of them get equal access and opportunity to learn mathematics. Encouragement is the next strategy used by the teachers to promote social justice in the classroom. Group work or collaborative learning can help students in forming ability groups to work on their pace and get support from the teacher as needed when other groups are working independently. Teachers expressed that they tend to link mathematics to students' daily life. Finally, as discussed above, all the strategies were used by the teachers for promoting social justice in the mathematics classroom. However, it does not mean that they are conscious of these practices all the time. These are the expressed views by the participants whereas the reality in the classroom may be different. It needs further study to understand teachers' practices of social justice in math classrooms. The views expressed by the three teachers and three students cannot be generalized for other schools and teachers in public schools in Nepal.

The findings from the study are indicatives of some possibilities of strategies for developing socially just pedagogical practice in math classroom. It may contribute in policy of social justice through equity and inclusiveness, social justice pedagogy as dreamt in the SSDP 2016/17-2022/23 and other policy documents and plans, and theory of social justice through the six conceptual constructs in the literature of social justice in education. Therefore, from this study, it can be concluded that the teachers who apply collaborative and problem-posing pedagogy with contextual and inclusive classroom approach through counseling, encouraging, grouping students, linking mathematics to daily life, personalizing instruction, promoting of joyful environment, and implementing class work and projects may promote social justice.

IJEME, Vol. 2, No. 1, March 2018, 17-38. 


\section{REFERENCES}

Allen, K. C. (2012). Keys to successful group work: Culture, structure, nurture. Mathematics Teacher, 106(4), 308-312.

Bartell, T. G. (2013). Learning to teach mathematics for social justice: Negotiating social justice and mathematical goals. Journal for Research in Mathematics Education, 44(1), 129-163.

Belbase, S. (2013). Images, anxieties, and attitudes toward mathematics. International Journal of Education in Mathematics, Science, and Technology, 1(4), 230-237.

Belbase, S., Luitel, B. C., \& Taylor, P. C. (2008). Autoethnography: A method of research and teaching for transformative education. Journal of Education and Research (JER), 1, 86-95.

Belbase, S. (2006). My journey of learning and teaching mathematics from traditionalisim to constructivism: A portrayal of pedagogical metamorphosis. M.Phil. Disseration, Kathmandu University, Nepal.

Berger, R. (2015). Now I see it, now I don't: Researcher's position and reflexivity in qualitative research. Qualitative Research, 15(2), 219-234.

Bhattachan, K. B. (2003). Indigenous nationalities and minorities in Nepal. A report submitted to Minority Rights Group International, London, UK.

Bold, C. (2012). Using narrative in research. London: Sage.

Bolyan, M. (2009). Engaging with issues of emotionality in mathematics teacher education for social justice. Journal of Mathematics Teacher Education, 12(1), 427-443.

Bolyan, M. \& Woolsey, I. (2016). Teacher education for social justice: Mapping identity spaces. Teaching and Teacher Education, 46(1), 62-71.

Brok, P.D., Fisher, D., \& Scott, R. (2005). The importance of teacher interpersonal behaviour for student attitudes in Brunei primary science classes. International Journal of Science Education, 27(7), 765-779.

Bull, B. (2009). Policy implications of social justice in education. Ethics and Education, $4(2), 141-152$.

Burton, L. (Ed.). (2003). Which way social justice in Mathematics education? London: Praeger.

Connor, C.M., Morrison, F.J., \& Katch, L.E. (2004). Beyond the reading wars: Exploring the effect of child-instruction interactions on growth in early reading. Scientific Studies of Reading, 8(1), 305-336.

Constantine, M.G., Hage, S.M., Kindaichi, M.M., \& Bryant, R.M. (2007). Social justice and multicultural issues: Implications for the practice and training of counsellors and counselling psychologist. Journal of Counseling and Development, 85(1), 24-29.

Curriculum Development Center (CDC). (2007). National curriculum framework for school education in Nepal. Sanothimi, Bhaktapur: Government of Nepal, Ministry of Education and Sports, Curriculum Development Centre.

Curriculum Development Centre (CDC). (2005). National curriculum framework for school education (pre-primary-12) in Nepal. Sanothimi, Bhaktapur: Government of Nepal, Ministry of Education and Sports, Curriculum Development Centre. 
Emma, L. (2015). The use of mathematics in everyday life. Retrieved from http://everydaylife.globalpost.com on 6th July 2015.

Esmonde, I., \& Caswell, B. (2010). Teaching mathematics for social justice in multicultural, multilingual elementary classrooms. Canadian Journal for Science, Mathematics, and Technology Education, 10(3), 244-254.

Falkenberg, T., \& Noyes, A. (2010). Conditions for linking school mathematics and moral education: A case study. Teaching and teacher education, 26(4), 949-956.

Garii, B., \& Appova, A. (2013). Crossing the great divide: Teacher candidates, mathematics and social Justice. Teaching and Teacher Education, 34, 198-213.

Gates, P. (2006). The place of equity and social justice in the history of PME. In A. Gutiérrez \& P. Boero (Eds.), Handbook of research on the psychology of mathematics education: Past, present and future (pp. 367-402). Rotterdam, The Netherlands: Sense Publishers.

Gregson, S.A. (2013). Negotiating social justice teaching: One full time teacher's practice viewed from the trenches. Journals for Research in mathematics education, 44(1), 164-198.

Gutiérrez, R. (2008). A gap-gazing "fetish in mathematics education? Problematizing research on the achievement gap. Journal for Research in Mathematics Education, $39(4), 357-364$.

Gutiérrez, R. (2009). Embracing the inherent tensions in teaching mathematics from an equity stance. Democracy and Education, 18(3), 9-16.

Gutstein, E. (2006). Reading and writing the world with mathematics: Toward pedagogy for social justice. New York: Routledge.

Gutstein, E. (2009). Developing social justice mathematics curriculum from students' realities. A case of Chicago public school. In W. Ayers, T. Quinn, \& D. Stovall (Eds.), Handbook of social justice in education (pp. 690-698). New York: Routledge.

Harrison, L. (2015). Teaching social justice through mathematics: A self-study of bridging theory to practice. Middle Grades Review, 1(1), 1-12.

Hay, C. (2011). Interpreting interpretivism interpreting interpretations: The new hermeneutics of public administration. Public Administration, 89(1), 167-182

Hempel-Jorgensen, A. (2015). Working-class girls and childcentred pedagogy: What are the implications for developing socially just pedagogy? International Studies in Sociology of Education, 25(2), 132-149.

Jacques, D. (1991). Learning in groups. London: Kogan Page.

John, E.P. (2007). Finding social justice in education policy: Rethinking theory and approaches in policy research. New Directions for Institutional Research, 33 (Spring 2007).

Jones, J.M., Sander, J.B., \& Booker, K.W. (2013). Multicultural competency building: Practical solutions for training and evaluating student progress. Training and Education in Professional Psychology, 7(1), 12-22.

Keddie, A. (2011). Educating for diversity and social justice. New York: Routledge.

IJEME, Vol. 2, No. 1, March 2018, 17-38. 
Kriflik, L. \& Mullan, J. (2007). Strategies to improve student reaction to group work. Journal of University Teaching and Learning Practice, 4(1), 13-27.

Lamichhane, B. R., \& Belbase, S. (2017). Images of mathematics held by undergraduate students. International Journal on Emerging Mathematics Education, 1(2), 147168.

Lim, C. S., \& Pateman, N. A. (2013). The politics of equity and access in teaching and learning mathematics. In M. A. (Ken) Clements et al. (Eds.), Third international handbook of mathematics education (pp. 243-263). New York, NY: Springer.

Luitel, B. C. (2009). Culture, worldview and transformative philosophy of mathematics education in Nepal: A cultural-philosophical inquiry. Doctoral dissertation, Curtin University of Technology, Perth, Australia.

Mathema, K. B., \& Bista, M. B. (2006). Study on student performance in SLC: Main report. Kathmandu, Nepal: Ministry of Education and Sports \& Education Sector Advisory Team.

Ministry of Education (MOE). (2017). School sector development plan 2016/172022/23. Kathmandu, Nepal: Government of Nepal/Ministry of Education.

Ministry of Education (MOE). (2015). Report on national assessment of student achievement (NASA) 2013. Bhaktapur, Nepal: The Author.

Moscardini, L. (2014). Developing equitable elementary mathematics classroom through teacher learning about children's mathematical thinking: Cognitively guided instruction as an inclusive pedagogy. Teaching and Teacher Education, 43, 69-79.

National Council of Supervisors of Mathematics and TODOS. (2016). Mathematics education through the lens of social justice: Acknowledgment, actions, and accountability. A Joint Position Statement from the National Council of Supervisors of Mathematics and TODOS: Mathematics for All. Online accessed from: http://www.todos-math.org/

National Council of Teachers of Mathematics (NCTM). (1989). Curriculum and evaluation standards. Reston, VA: NCTM.

National Council of Teachers of Mathematics (NCTM). (2000). Principles and standards for school mathematics. Reston, VA: NCTM.

Nurmi, J. E., Viljaranta, J., Tolvanen, A., \& Aunola, K. (2012). Teachers adapt their instruction according to students' academic performance. Educational Psychology, 32(5), 571-588.

Panthi, R. K., Luitel, B. C., \& Belbase, S. (2018). Teachers' perception of social justice in mathematics classrooms. REDIMAT Journal of Research in Mathematics Education, 7(1), 7-37.

Panthi, R. K., \& Belbase, S. (2017). Teaching and learning issues in mathematics in the context of Nepal. European Journal of Educational and Social Sciences (EJESS), 2(1), 1-27.

Panthi, R. K. (2017). Social justice in mathematics classroom: An interpretive inquiry. M. Phil. Dissertation. Nepal: Kathmandu University. 
Pekrun, R. (2006). The control-value theory of achievement emotions: Assumptions, corrllaries, and implications for educational research and practice. Educational Psychology Review, 18(4), 315-341.

Planas, N., \& Civil, M. (2009). Working with mathematics teachers and immigrant students: An empowerment perspective. Journal of Mathematics Teacher Education, 12(6), 391-409.

Plunkett, D. (2013). Dworkin's interpretivism and the pragmatics of legal disputes. Legal Theory, 19(3), 242-281.

Reissman, C.K. (2008). Narrative methods for the human sciences. Thousand Oaks, CA: Sage.

Ronkainen, N.J., Watkins, I., \& Ryba, T.V. (2016). What can gender tell us about the preretirement experiences of elite distance runners in Finland? A thematic narrative analysis. Psychology of Sport and Exercise, 22(1), 37-45.

Rytivaara, A., \& Vehkakoski, T. (2015). What is individual in individualized instruction? Five storylines of meeting individual needs at school. International Journal of Educational Research, 73, 12-22.

Sakiz, G., Pape, S.J., \& Hoy, A.W. (2012). Does perceived teacher affective support matter for middle school students in mathematics classrooms? Journal of School Psychology, 50(2), 235-255.

Taylor, P.C., \& Luitel, B.C. (2005). Overcoming culturally dislocated curricula in a transitional society: An autoethnographic journey towards pragmatic wisdom. Paper presented at the annual meeting of the American Educational Research Association (AERA), SIG: Self-Study of Teacher Education Practices Montreal.

Thrupp, M., \& Tomlinson, S. (2005). Introduction: education policy, social justice, and 'complex hope'. British Educational Research Journal, 31(5), 549-556.

Tomlinson, C.A. (1999). The Differentiated classroom: Responding to the needs of all learners. Alexandria, VA: The Association for Supervision and Curriculum Development (ASCD).

UNESCO Kathmandu Office. (2015). Education for all: National review report 2001 2015. Kathmandu, Nepal: The Author.

UNESCO Kathmandu Office. (2011). Multilingual education in Nepal: Hearsay and reality? Kathmandu, Nepal: The Author.

Villegas, A.M. (2007). Dispositions in teacher education: A look at social justice. Journal of Teacher Education, 58(5), 370-380.

Vomvoridi-Ivanovic, E., \& McLeman, L. (2015). Mathematics teacher educators focusing on equity: Potential challenges and resolutions. Teacher Education Quarterly, 42(4), 83-100.

Webel, C. (2013). Classroom collaboration: Moving beyond helping. Mathematics Teacher, 106(6), 464-467.

Wright, P. (2016). Social justice in the mathematics classroom. London Review of Education, 14(2), 104-118.

Zhu, C. (2013). Students' and teachers' thinking styles and preferred teacher interpersonal behavior. The Journal of Educational Research, 106(5), 399-407.

IJEME, Vol. 2, No. 1, March 2018, 17-38. 